\title{
Effect of Using the Electronic Mind Map in the Educational Research Methodology Course for Master-Degree Students in the Faculty of Education
}

\author{
T. Tungprapa
}

\begin{abstract}
The objective of this article is to study results of using the electronic mind map for the teaching and learning in educational research methodology course of Master's degree students in the Faculty of Education, Ramkhamhaeng University, Thailand by using quantitative and qualitative study. Study samples include one class of master degree students. Research tools are comprised of an attitude assessment - pre-study and post-study - form, a questionnaire, and an interview form. Analysis of quantitative data was performed by using fundamental statistics, the $t$ - test (dependent) and the $t$ - test (independent) while qualitative data was analyzed by using the content analysis technique.

Results of quantitative study showed that the Free Mind program is the software mostly used by students to create mind map. After the electronic mind map was used, it was found that the students' post-study attitudes towards the research study subject are higher than their pre-study attitudes, at 0.05 level of statistical significance. In addition, the students considered that application of mind map is useful at the highest level. Meanwhile, results of qualitative study indicated that students had perceived usefulness of applying mind map into the research learning session. However, the teachers' own teaching and knowledge transfer techniques are still considered as an important part that improves students' knowledge and creates students' positive attitudes towards research.
\end{abstract}

Index Terms-Electronic mind map, research methodology course, quantitative and qualitative study.

\section{INTRODUCTION}

Research is considered as an important subject for postgraduate students as they have to apply knowledge learned from this subject for using in their own research in postgraduate studies. Besides, such knowledge shall also be applied in their researches after graduation. The Faculty of Education, Ramkhamhaeng University, has perceived significance of research methodology studies so that it requires master degree students in all fields of studies to register research study as a fundamental subject in their course [1].

Although considered as an important subject for students, most of students have, however, rather negative attitude towards the research study as they perceive that this is a difficult subject, which is very comprehensive and difficult to understand. The researcher, as an instructor of the research methodology subject, has applied the electronic mind map

Manuscript received May 6, 2014; revised July 8, 2014.

T. Tungprapa is with the Department of Evaluation and Research, Faculty of Education, Ramkhamhaeng University, Bangkok, Thailand (e-mail: tavi.ouy@gmail.com). for the teaching and learning session of educational research methodology course for graduate students of the Faculty of Education, Ramkhamhaeng University, in order to solve the aforementioned attitudinal problems because it is perceived that mind mapping is a creativity-and productivity-enhancing technique that can improve the learning and efficiency of individuals and organizations. It is a revolutionary system for capturing ideas and insights horizontally on paper. "It can be used in nearly every activity where thought, planning, recall or creativity are involved" [2]. Besides, as indicated by Jones, Pierce, \& Hunter [3], a good mind mapping enables learners to perceive relationships of the main concepts of a specific issue and gain understanding and concept of the subject more quickly and better than trying to understand from verbal explanation alone. Besides, results from several researches show that use of mind maps can significantly enhance learning, memory, motivation and creativity of students [4]-[10].

Traditionally, mind maps were drawn with colored pens and paper. With presently available technology, it is possible to create mind map by using computer, which makes it easy to make, review, revise, and save mind maps. Moreover, such computer technology is very useful in creating more beautiful presentations. This research studied, quantitatively and qualitatively, on the outcome of application of the electronic mind map for the research teaching and learning session of the educational research methodology course. Findings shall be used for improvement and more efficiency of teaching and learning session.

\section{ReSEARCh OBJeCtive}

This research aims to study results of using the electronic mind map for the teaching and learning of educational research methodology course of master-degree students in the Faculty of Education, Ramkhamhaeng University, by using quantitative and qualitative study.

\section{RESEARCH METHOD}

This research was carried out using both quantitative and qualitative methods. Samples for study, research tools, research methods, and data analysis are as follows.

Study samples used in this research are master degree students of the Faculty of Education, Ramkhamhaeng University, who registered for the subject MER6903 (Educational Research Methodology) in Semester 1 of the academic year 2012. Samples are selected by using cluster 
random sampling technique. Sample group comprises 27 master degree students from one class of the teaching of social science major.

Tools used in this research is comprised of 4 sets of documents, which are 1) a pre-study attitude assessment form, 2) a post-study attitude assessment form, 3) a questionnaire on usefulness of the electronic mind-map, and 4) an interview form on applications of the electronic mind-map in teaching and learning session of educational research methodology.

Research was conducted by using the following methods.

1) Before teaching session: the instructor assessed students' attitudes towards the research subject.

2) During teaching session: the instructor asked students to create mind map by using a computer program for summarizing contextual concepts for each topic of the educational research methodology and submit to the instructor after teaching session of each topic. The instructor examined and gave advice to students regarding the mind map that the created.

3) After teaching session: the instructor assessed students' attitudes towards the research subject and asked students to respond via the opinion survey questionnaire. Then, students were interviewed concerning applications of the electronic mind-map in teaching and learning session.

Quantitative data analysis was carried out using fundamental statistics including frequency, percentage, mean, standard deviation, with criteria of data interpretation. The dependent sample t-test and the independent sample t-test were also used. For qualitative analysis, the content analysis was used.

\section{RESEARCH RESULTS}

Research results comprise quantitative and qualitative results and can be summarized as follows.

\section{A. Results of Quantitative Study}

\section{1) Software for creating the mind map}

The software that is used by most students to create mind maps is FreeMind (38.71\%), followed by the MindManager (25.81\%), Edraw MindMap (19.35\%), and XMind (12.90\%) respectively. Besides, there was also a student who used Buzan's iMindMap program. Details are shown in Fig. 1 and Table I.

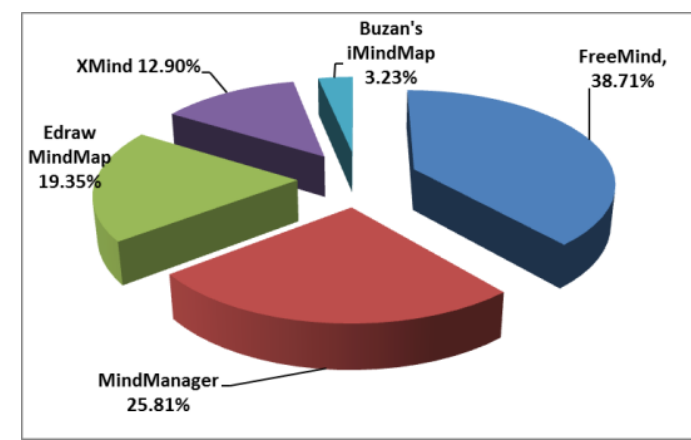

Fig. 1. Software used by students to create mind maps.

\section{2) Mind maps created by students}

Electronic mind maps that are created by students using computer program are in several styles, as shown in Fig. 2.
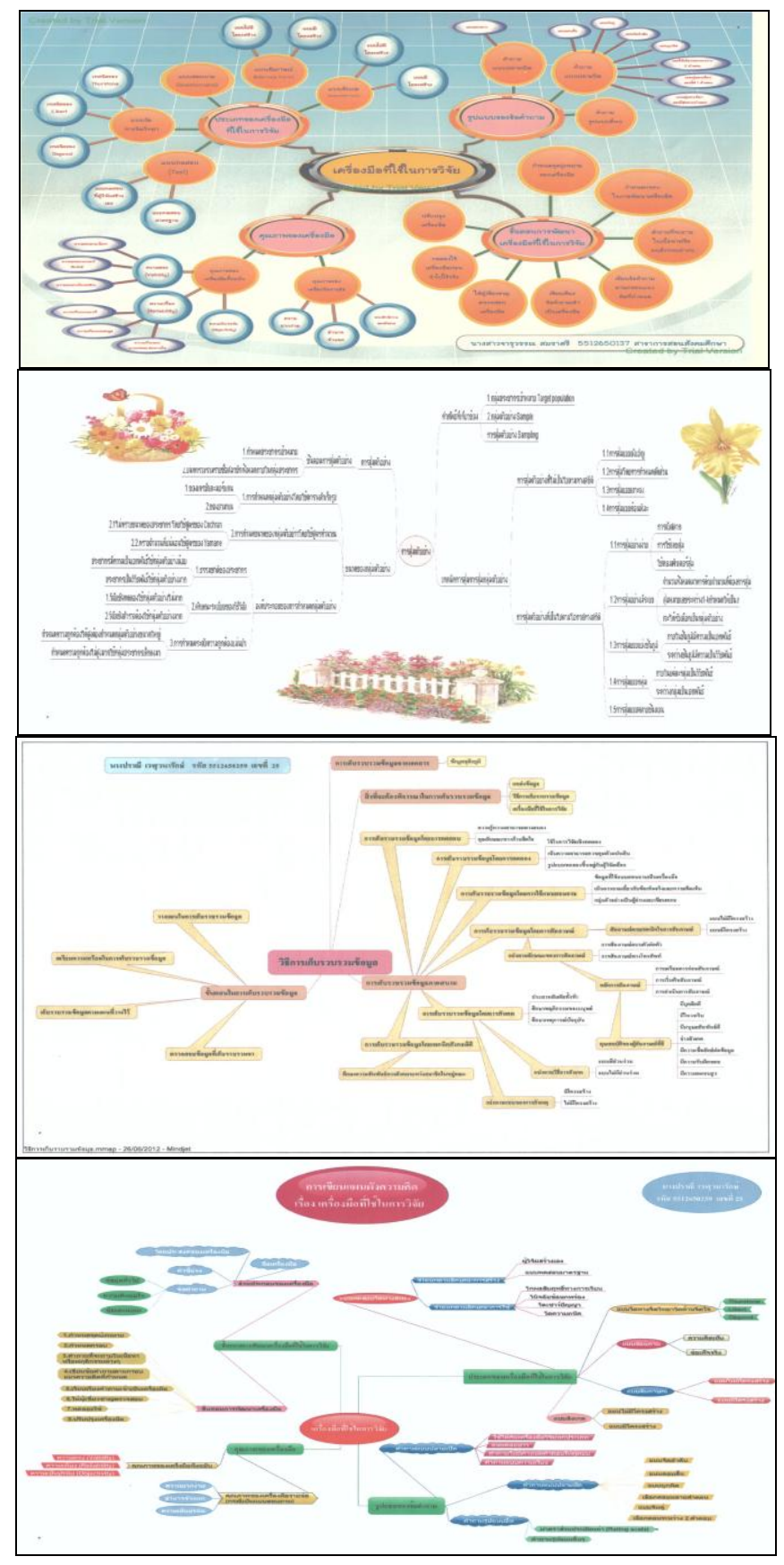

Fig. 2. Examples of electronic mind maps created by students.

\section{3) Comparisons of pre-study and post-study attitudes towards research subject of students}

Students' attitudes towards research subject, overall and on specific aspects of knowledge, emotion, and behavior were assessed. The results show that their post-study attitudes after learning session, by using electronic mind map, were higher, when comparing with the pre-study attitudes, at statistical significance level of 0.05 . Details are shown in Table II.

\begin{tabular}{|c|c|c|c|}
\hline No. & Software & $\mathbf{N}$ & $\%$ \\
\hline 1 & FreeMind & 12 & 38.71 \\
\hline 2 & MindManager & 8 & 25.81 \\
\hline 3 & Edraw MindMap & 6 & 19.35 \\
\hline 4 & XMind & 4 & 12.90 \\
\hline 5 & Buzan's iMindMap & 1 & 3.23 \\
\hline & Total & 31 & 100.00 \\
\hline
\end{tabular}


TABLE II: COMPARISONS OF PRE-STUDY AND POST-STUDY ATTITUDES TOWARDS RESEARCH SUBJECT OF STUDENTS

\begin{tabular}{ccccccc}
\hline Attitudes & Score & $N$ & $\bar{X}$ & S.D. & $t$ & $p$ \\
\hline \multirow{2}{*}{ Knowledge } & Post-study & 27 & 4.04 & 0.47 & $4.175^{*}$ & 0.000 \\
& Pre-study & 27 & 3.64 & 0.46 & & \\
\hline \multirow{2}{*}{ Emotion } & Post-study & 27 & 3.97 & 0.52 & \multirow{2}{*}{$4.498^{*}$} & 0.000 \\
& Pre-study & 27 & 3.57 & 0.51 & & \\
\hline \multirow{2}{*}{ Behavior } & Post-study & 27 & 4.46 & 0.36 & \multirow{2}{*}{$5.868^{*}$} & 0.000 \\
& Pre-study & 27 & 3.99 & 0.42 & & \\
\hline \multirow{2}{*}{ Overall } & Post-study & 27 & 4.16 & 0.38 & $5.677^{*}$ & 0.000 \\
& Pre-study & 27 & 3.73 & 0.42 & & \\
\hline
\end{tabular}

(*Statistical Significance Level of 0.05)

TABLE III: COMPARISON OF PRE-STUdy AND POST-STUDy ATtITUDES TOWARDS RESEARCH SUBJECT OF STUDENTS WITH DIFFERENT LEVEL OF RESEARCH

\begin{tabular}{|c|c|c|c|c|c|c|c|c|c|c|}
\hline \multirow[b]{2}{*}{ Attitudes } & \multirow{2}{*}{$\begin{array}{c}\text { Research } \\
\text { Experience }\end{array}$} & \multirow[b]{2}{*}{$N$} & \multicolumn{4}{|c|}{ Pre-study } & \multicolumn{4}{|c|}{ Post-study } \\
\hline & & & $\bar{X}$ & S.D. & $t$ & $p$ & $\bar{X}$ & S.D. & $t$ & $p$ \\
\hline \multirow[b]{2}{*}{ Knowledge } & $\begin{array}{c}\text { Students with } \\
\text { previous research } \\
\text { experience }\end{array}$ & 15 & 3.73 & 0.49 & \multirow[t]{2}{*}{0.626} & \multirow[t]{2}{*}{0.538} & 4.10 & 0.48 & \multirow[t]{2}{*}{0.252} & \multirow[t]{2}{*}{0.804} \\
\hline & $\begin{array}{c}\text { Students without } \\
\text { previous research } \\
\text { experience }\end{array}$ & 7 & 3.60 & 0.46 & & & 4.05 & 0.38 & & \\
\hline \multirow{2}{*}{ Emotion } & $\begin{array}{c}\text { Students with } \\
\text { previous research } \\
\text { experience }\end{array}$ & 15 & 3.69 & 0.50 & \multirow{2}{*}{1.438} & \multirow{2}{*}{0.166} & 4.00 & 0.50 & \multirow{2}{*}{0.593} & \multirow{2}{*}{0.560} \\
\hline & $\begin{array}{c}\text { Students without } \\
\text { previous research } \\
\text { experience }\end{array}$ & 7 & 3.36 & 0.52 & & & 3.86 & 0.59 & & \\
\hline \multirow{2}{*}{ Behavior } & $\begin{array}{c}\text { Students with } \\
\text { previous research } \\
\text { experience }\end{array}$ & 15 & 4.11 & 0.42 & \multirow{2}{*}{$2.222 *$} & \multirow{2}{*}{0.038} & 4.42 & 0.35 & \multirow{2}{*}{-0.736} & \multirow{2}{*}{0.470} \\
\hline & $\begin{array}{c}\text { Students without } \\
\text { previous research } \\
\text { experience }\end{array}$ & 7 & 3.73 & 0.23 & & & 4.53 & 0.24 & & \\
\hline \multirow{2}{*}{ Overall } & $\begin{array}{l}\text { Students with } \\
\text { previous research } \\
\text { experience }\end{array}$ & 15 & 3.84 & 0.42 & \multirow{2}{*}{1.508} & \multirow{2}{*}{0.147} & 4.17 & 0.38 & \multirow{2}{*}{0.169} & \multirow{2}{*}{0.868} \\
\hline & $\begin{array}{l}\text { Students without } \\
\text { previous research } \\
\text { experience }\end{array}$ & 7 & 3.56 & 0.38 & & & 4.14 & 0.35 & & \\
\hline
\end{tabular}

(*Statistical Significance Level of 0.05. Remark: There are total of 22 students with defining research experience data)

4) Comparison of pre-study and post-study attitudes towards research subject of students with different level of research experiences

Studying on attitudes towards research subject among students, with different level of research experiences, found that their pre-study attitudes, in the overall, knowledge and emotion aspects, were not statistically different at level 0.05 while the attitudes in the behavior aspect were found to be statistically different at level 0.05. After application of electronic mind map in the lesson of educational research methodology, it was found that the attitudes towards research subject, in all aspects, among both group of students, had increased and their attitudes were not statistically different at level 0.05. Details are as shown in Table III.

\section{5) Opinions on usefulness of the electronic mind map}

Students opined that the electronic mind-mapping is very highly useful $(\bar{X}=4.52)$. When considering in each specific aspect, it was found that the electronic mind-mapping is highly useful for development of thinking system $(\bar{X}=4.48)$ and applications of the electronic mind map in teaching and learning is very highly useful $(\bar{X}=4.55)$ from the full score of 5.00. Details are shown in Table IV.

TABLE IV: OPINIONS ON USEFULNESS OF THE ELECTRONIC MIND MAP

\begin{tabular}{lccc}
\hline \multicolumn{1}{c}{ Description } & $\bar{X}$ & S.D. & Interpretation \\
\hline $\begin{array}{l}\text { 1. Usefulness of the electronic } \\
\text { mind-mapping for } \\
\text { development of thinking } \\
\text { system }\end{array}$ & 4.48 & 0.47 & Highly useful \\
\hline $\begin{array}{l}\text { 2. Usefulness of the } \\
\text { applications of the } \\
\text { electronic mind map in } \\
\text { teaching and learning }\end{array}$ & 4.55 & 0.49 & $\begin{array}{c}\text { Very highly } \\
\text { useful }\end{array}$ \\
\hline Overall Average & $\mathbf{4 . 5 2}$ & $\mathbf{0 . 4 7}$ & $\begin{array}{c}\text { Very highly } \\
\text { useful }\end{array}$ \\
\hline
\end{tabular}

\section{B. Results of Qualitative Study}

Results of qualitative study obtained from interviews with 10 students were summarized that applications of mind map in research study has enabled students to more easily 
understand the content, perceive relations between contents, and memorize the overall concept of the research. In addition, using computer programs is useful to create beautiful mind maps which can be used with better efficiency such as making presentations. However, the instructor's method of teaching and transferring knowledge is still considered as an essential part that leads to students' improved knowledge and attitudes towards their studies. Applications of new techniques such as creating mind map by using computer can enhance organizing students' thinking system and can be regarded as a supportive means for higher efficiency in learning research methodology.

Examples of specific issues from interviews:

\section{Student 1}

"At first, I thought that the research subject is quite difficult and I did not want to study. Using mind map in this subject helped me better understand and memorize the overall concept of the research subject. Also, the instructor's technique in teaching created better feeling for students. I like the way that the instructor transferred the knowledge because it is easy to understand and not complicated. From the previous dislike of research subject, after I studied I began to like it and also wish to do research. I think the instructor's technique plays an important part of making students wishing to learn this subject. Also, using new techniques such as creating mind map by using computer in organizing thinking system is an important means that supports learning research subject with higher efficiency.",

\section{Student 2}

"Making mind map enables student to collect a lot of learning contents into a single sheet of paper, making it easy to understand the content, revise and summarize the knowledge, which helps students to easily capture main points. As such, this approach helps to more easily understand the comprehensive content of research subject so that students had less fear of the research subject. Besides, I think I would like to apply mind map into my future classes when I have to teach students my responsible subjects."

\section{Student 3}

"Making mind maps is a way to summarize the thoughts and further expand the thoughts while making it easier to understand the difficult subjects better. The teacher is most important. If the teacher teaches this subject by using books only, it is very hard to understand. When the teacher can explain to make it easier to understand, the lesson becomes more interesting and more fun. The teacher paid great attention to students and that made the class which was perceived to be boring became a much more enjoyable class. Besides, the teacher had tried to help students by asking them to summarize their thoughts and learned lessons, which made it easier to understand this subject. I also think that I will apply the mind map software to summarize contents of the subjects as a preparation for the exam as well as planning for my work in the future."

\section{Student 4}

"Actually, I have already taught my students to create mind map but I have never applied it for my own use. When I have attended this lesson, I now have some ideas to apply mind map for actual use. Before this, I never knew how people have created beautiful mind maps, as I knew only how to make mind map by hand-drawing. When I had chance to create mind map by using computer, I have many new ideas because using computer to create mind map allows us to convert it to many other formats and it can be modified and stored for future uses, which is considered very useful. However, creating mind map alone cannot make students to wholly understand and gain knowledge from the subject. In research lessons, the teacher had a systematic teaching method with relevant contents in order and easy to understand. Besides, the teacher taught by using the problems and causes approach. Students received clear and explanation with research reasons. Moreover, the teacher was quite relaxed and not stressed, and friendly, as well as always trying to explain and give students opportunity to ask questions. As such, it made research subject, which seems to be a subject that is difficult to understand, much more easy to understand."

\section{SUMMARY AND CONCLUSIONS}

Application of electronic mind map in teaching the educational research methodology course for master degree students of the Faculty of Education, Ramkhamhaeng University, was studied. Results of quantitative study revealed that students could create the electronic mind map. The software that is mostly used for creating the mind map is FreeMind program $(38.71 \%)$. After applying the electronic mind map in teaching session, students' attitudes towards research subject, both for overall and specific aspects such as knowledge, emotion, and behavior, have increased with statistical significance level at 0.05, when compared with the pre-study attitudes. Besides, it was found that, before study, students with previous research experience had higher attitudes on the behavioral aspect than students without prior research experience. After application of electronic mind map, the overall attitude, of both groups of students, towards the research subject is higher than that before the lesson and such results from both groups are not statistically different at level of 0.05 . When considering students' opinion on creating the mind maps, it was found that students considered applications of mind maps and the electronic mind map for teaching and learning session is very highly useful (mean value is 4.52 from a full score of 5.00). Meanwhile, the qualitative study found that application of the mind map in this subject has enabled students to more easily understand the content, perceive relations between contents, and memorize the overall concept of the research. However, the instructor's method of teaching and transferring knowledge is still considered as an essential part that improves students' knowledge and attitudes towards their studies. Applications of new techniques for using mind map is considered as a supportive means for learning research with higher efficiency. 


\section{REFERENCES}

[1] Ramkhamhaeng University, Manual for postgraduate studies in academic year 2012, Bangkok: Ramkhamhaeng University Printing Press. 2012.

[2] T. Buzan, Use both sides of your brain, 3rd ed., New York, NY: Plenum, 1989

[3] B. R. Jones, J. Pierce, and B. Hunter, "Teaching students to construct graphic representations," Educational Leadership, vol. 46, no. 4, pp. 21-25, 1989.

[4] J. A. Mento, P. Martinelli, and M. R. Jones, "Mind mapping in executive education: Applications and outcome," The Journal of Management Development, vol. 18, no. 4, pp. 390-407, 1999.

[5] P. Farrand, F. Hussain et al., "The efficacy of the 'mind map' study technique," Medical Education, vol. 36, no. 5, pp. 426-431, 2002.

[6] A. V. D'Antoni and G. P. Zipp, “Applications of the mind map learning technique in Chiropractic Education: A pilot study and literature review," Journal of Chiropractic Humanities, vol.13, pp. 2-11, 2006.

[7] H. Toi, "Research on how mind map improves memory," presented at the 14th International Conference on Thinking, Kuala Lumpur, June 22-26, 2009.

[8] R. Al-Jarf, 'Enhancing freshman students' writing skills with a mind mapping software," presented at the 5th International Scientific Conference, eLearning and Software for Education, Bucharest, April 9-10, 2009.
[9] Riswanto and P. P. Putra, "The use of mind mapping strategy in the teaching of writing at SMAN 3 Bengkulu, Indonesia," International Journal of Humanities and Social Science, vol. 2, no. 21, pp. 60-68, 2012.

[10] S. O. Adodo, "Effect of mind-mapping as a self-regulated learning strategy on students' achievement in basic science and technology," Mediterranean Journal of Social Sciences, vol. 4, no. 6, pp. 163-172, 2013.

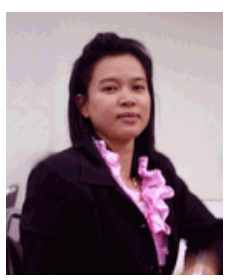

T. Tungprapa received the Ph.D. in educational measurement and evaluation from Chulalongkorn University in Thailand.

She worked as the director of Quality Assurance Office and a lecturer of Mahanakorn University of Technology, Thailand. At the moment, she is a full-time lecturer at Ramkhamhaeng University in the Department of Evaluation and Research, Faculty of Education, Thailand. In addition, she is an assessor for internal quality assurance supported by Office of the Higher Education Commission (OHEC), Thailand.

Dr. Taviga Tungprapa's current work includes qualitative and quantitative research on teaching and learning, educational quality assurance, management in higher education and project evaluation. 